\title{
Changing Perceptions or Keeping Things As They Are...???????????
}

\author{
Ms.Samina Najeeb \\ PhD Scholar NUML University, Islamabad Pakistan.
}

\begin{abstract}
The following article deals with the role of media in creating peace and tolerance among societies and cultures across the world. People today greatly depend on media for local, national and international news. It would not be an exaggeration to say that digital, electronic and print media is a record of our civilization. Wars are fought and won on media today. Media can very insidiously shape and transform societies. Besides imparting social, cultural and commercial messages, it can be a harbinger of peace for the world: for its' strength and effectiveness lies with the democratic traditions and conventions besides political, social and cultural awareness and consciousness of the multiple societies and subcultures around the world. Human beings are psychologically conditioned by certain habits, prejudices and stereo typed thinking, which hinders in cross cultural communication. This paper calls upon the media gurus to change perceptions by bringing into the limelight the positive values of tolerance, forgiveness, respect and empathy which can unite us in diversity.

Key Words: media, cross cultural communication, empathy, tolerance, cognitive dissonance, pluralistic society, culture, globalization.
\end{abstract}

\section{Introduction}

The paper studies the socio political affairs of the world and the powerful role that media plays in the world scenario today. The greatest challenge for the people of the world is to accept the "Other". If we succeed in doing it, this world would become a utopia. Media is the only tool that can unite us all in diversity. As a researcher I have dilated upon the societal role of media in addition to infotainment and any propagandist agenda that the media gurus may choose to play.

\section{Discussion}

Aristotle, the father of western philosophy invited the world to ponder over his words, when in a direct and overt vitriolic tone, he declared that "a person who cannot live in society or does not need to, because he is self sufficient is either a beast or a god" (Politics I, cf. Francis Bacon1:65)

The above quoted maxim is universally acknowledged by people of all ages, races, gender, creeds and professions that man is a social animal. His fondness of living in groups, communities or nations is linked to his emotional, psychological and biological needs.

Gregariousness according to psychologists is because of two reasons. Man is easily affected by sympathy and the desire for sympathy and prefers company to solitude. He desires to be loved, admired, respected and likes to reciprocate these feelings in others. These biological and emotional needs compel us to live in the company of others.

Media holds a significant place in our world today. We may be living in geographically distributed groups but thanks to media we communicate interactively and simultaneously through text, sound and video. All around the world, media is used as an entity around which an individual's life, the political affairs, economic struggles and our state affairs revolve. It will not be an exaggerated comment, if we say media is a pillar of any state. Media is a large scale tool of communication that affects the perceptions of the peoples of the entire world. Edward Sapir recognizes communication to be a fundamental process. He believes that communication is a " highly intricate network of partial or complete understandings between the members of organizational units of every degree of size and complexity-ranging from a pair of lovers, or family to a league of nations or that ever increasing portion of humanity which can be reached by the process, through all its transnational ramifications" Edward Sapir.

If the influence of media is so pervasive, then Wilbur Shram is justified in holding the opinion that media is a vehicle for sharing information and ideas or attitudes. If media creates perceptions then it is extremely important that the message that it sends must suit the people of all social and cultural groups. A message that does not take into account, the cultural and social values of the people, will most certainly result in producing a negative response or a non-compliance, which will result in complete failure and breakdown in the process of communication. Whether the channel of communication is Internet, television, radio, cable, 
newspapers, a news item or documentary or a film, if it does not respect and honor the gregarious nature of man, then, it is sure to fail.

The psychologists deduce that human beings learn through their senses. Eleven percent of learning in humans takes place through hearing and eighty three percent through sight; therefore those mediums which comprise both hearing and viewing are more powerful sources of learning. Therefore we can very safely say that the world of Internet and television can be considered more pervasive, as compared to radio and newspaper mediums.

The ray of hope in this world torn apart by war, strife, massive killings, seriously religiously motivated conflicts, genocide and seriously committed crimes against humanity is media. What is so heart rendering is that people of this world are fighting in the name of race or religion!! Ironically speaking, none of us follow religions in their true spirit and yet we fight over our religions. All the divine books and all prophets and religious leaders have endeavored to imbibe the values of love, respect for each other's beliefs and values and tolerance for other faiths. Yet their followers hold grudges and grievances and do not want to let go of their stereotypical views. Leon Festinger, an American sociologist, calls this phenomenon the "theory of cognitive dissonance", meaning that people believe in something but act otherwise i.e. contrary to their beliefs and knowledge.

Inconsistencies and conflicts between one's beliefs and actions have psychological implications. People endeavor to reduce or minimize this dissonance by managing changes in their actions or by altering their beliefs, opinions and dogmas. International media was used to justify inhuman civilian killings in Iraq and Afghanistan, using media insidiously to justify massacre by calling these brutal killing as "surgical bombings". The political powers used this propaganda of surgical bombings to justify their actions by the process of "dissonance reduction".

Noam Chomsky, the greatest linguist of the twentieth century, an author of several books on social and political issues in his book "Manufacturing Consent" concludes that "the societal purpose of the media is to defend the economic, social and political agenda of privileged groups that dominate the domestic society and the state"

The world of media changes perceptions of the people by persuasive communication. An important psychological fact is that mentally and psychologically people establish warm contacts and warm relations with people having similar views. The age old adage, "birds of a feather flock together" holds true even today. Media works in the same manner, influencing and molding opinions and perceptions of the general public thus assuming the role of leadership or opinion makers. This mode of opinion forming role is exploited to maximum by the political powers to venture change and to assist them in generation of particular public opinion. This is the reason why media is used all over the world to disseminate the idea that, grave enemies are about to attack us and we need to stick together under the aegis of domestic power.

Political powers use such kind of propaganda to frighten people with, to distract them so that they are unable to pay attention to the serious issues aroused by social and economic conditions. Media has been optimally used to engender fear and hatred among people of diverse cultures, to channel public rage that is aroused not by difference of religion or race or culture, but by the discontent that is the result of poverty, injustice, joblessness, inflation and corruption, which are rampant in all the societies of the world.

If there is a clash between Muslims and non-Muslims, it is because the media has done its' utmost to project men with beards and turbans to be terrorists!!! All women wearing a veil are categorically declared to be dim witted and oppressed. We must not forget that no religion, not even Islam allows innocent killings. We must also remember that the oppressed people of Afghanistan would not have supported the Taliban if their government would have served the Afghani nation conscientiously.

Remember that reality is always socially created. It depends upon the sort of experiences people have in their lives and what sort of opportunities they have to change the structure and people will choose different options .If the international media promotes a culture of plurality and collectivism then all the diverse cultures will reciprocate mutual respect and tolerance.

What is happening with media is that elites that have a strong influence on media. They regard democracy, equity and justice as major threats, something to be defended against. It is understood by the powers of the world that the best defense against democracy is to distract people. Divide and rule has been the rule for exercising power over the larger masses. Therefore media is used as a tool to create hype so that non issues are made to appear as serious issues to distract the public from matters of serious concern.

The common folks of the developed and industrialized countries have to work as long as eighteen hours to lay food on their tables. They have no time to analyze the policies of the governments nor do they have the time to think about the issues of the third world nations, nor are they concerned about the issues of the less privileged people living on the other side of the world. They easily absorb the information that is bombarded at them by the T.V, Internet or the Newspapers. The people trust the opinion leaders, the media gurus, who take 
special care to communicate messages according to the language, style, traditions of the group or society s/he belongs to or lays social, cultural and ideological allegiance to.

The onus of responsibility lies on the media for spreading awareness about the need to respect cultural diversity. The reason why media can play a significant role in this regard is because the majority of the people of the west trust it and those of the pre-modern or the developing societies are mostly illiterate and therefore rely on TV and radio for information about what is happening around the world. The people of the third world suffer from problems like illiteracy, mal nourishment, joblessness and diseases that the people of the west have succeeded in getting rid of, ages ago. Unhealthy living conditions, lack of clean drinking water, drone attacks, terrorist attacks and corrupt leaders are the forms of hardships that they endure. If the people of such societies are shown by media that the people who belong to the developed nations look down upon them, their customs and their religious beliefs, then the unprivileged class would feel alienated from the dominant culture and seek opportunities to challenge or contest it. The media must frame stories, documentaries and programs in different languages to enable people from diverse cultures to interpret cross cultural differences in different countries and even subcultures within the country.

In other words we must learn to think sociologically, i.e looking at the broader view_meaning " we will have to cultivate our imagination", to quote the American author C Wright Mills, in a famous phrase, called the sociological imagination (Mills 1970 ).The sociological imagination requires us to look at our familiar lives, anew.

Before we talk further about the role of media in creating tolerance around the world, we must understand the concept of culture and society. Culture refers to the "ways of life of the members of a society, or of groups within the society. It includes how they dress, their marriage customs and family life, their work patterns, religious ceremonies and leisure pursuits".Britain, France and United States are societies in this sense. They include millions of people. No cultures could exist without societies and vice versa. In other words it is the culture that distinguishes human beings from animals. The diversity of human culture is remarkable. Acceptable forms of behavior vary widely from culture to culture, often contrasting in a radical way with what people from the western societies consider normal.

Oysters are eaten in the west, but not kittens, puppies or monkeys, which are enjoyed as delicacies in some parts of the world. Muslims and Jews do not eat pork, while Hindus eat pork but avoid beef and chicken. A veiled woman may be a symbol of oppression in the west but the east regards wearing a veil modest. All these different traits of behavior are aspects of broad cultural differences which distinguish societies from one another. Killing of female infants will most certainly be regarded as brutal by all of us, but, in traditional Chinese and Indian cultures a girl child is strangled at birth or the fetus (female) is aborted, not because they hate girls but because these cultures regard a girl child to be a liability rather than an asset to the family.

We need to understand the beliefs and mores or cultural practices in proper context. We cannot understand these separately from the wider cultures of which they are a part. A specific culture has to be studied in terms of its own meanings and values.

If you were to walk down into a local shop or supermarket in Pakistan, you would find all foreign brands on the shelves there. Brand names like St. Michael's, Levi, Gucci, Nike, Garnier, L'Oreal, Christian Dior, Samsonite, Puma, Hardy's, KFC and McDonalds are there for the consumer, with the money to enjoy these items. The products are available because of the economic connections stretching across the world. The anthropologist Peter Worsley ( Worsley 1984, P.1) writes " until our day, human society has never existed ". What he probably means is that it is only in recent times that our world has become a single social system, as a result of growing ties of inter dependence. Pakistan for example is one of the largest exporters of Mango fruit, cotton and rice. If the global system comprises social, political and economic connections cross cut borders between countries, then these factors decisively condition the fate of those living within each of them.

Today we live in a Global village, where no society on earth can live in isolation from others, and even the wealthiest nations are dependent on goods and labor from abroad. In America and Britain, nearly all TV sets sold are made and assembled in Far East.

"A Ford Mondeo car, for example, involves parts made in 112 different locations, spanning 16 countries and 3 Continents."

Globalization has brought numerous benefits to us but it has also created serious problems, we now face. I would like to quote a classic study by an American sociologist, Eugene Hartley in 1946, who investigated attitudes towards 35 ethnic minorities and found that those prejudiced against one ethnic group were likely to express negative feelings against each other. Jews and African Americans were disliked as much as Wallonians, Pireneans and Daniveans (Hartley 1946). The three latter groups were non existent. Hartley coined these names to see whether people would be prejudiced against groups they could not have even heard of. This psychological mechanism of stereo typical thinking has resulted in ethnocentrism. In Heidegger's view," our own being as agents of specific types is defined by the world into which we are thrown....our identity as agents is made possible by the context of shared forms of life and linguistic practices of a public life world. For the most part 
we exist as they" Not only do we play stereo type roles in our society but we also regard the others as "them"!!! It is 'Us' and 'Them.'

Recent philosophical thought has witnessed a resurgence of interest in pluralism. This is evident in the development of American Pragmatism, where pluralism received piquant expression in James A Pluralistic Universe (1909). We call upon the media to proclaim that the unities and totalities of thought, discourse and action be subverted in the interest of reclaiming the diversified and heterogeneous world of human experience.

It is indeed now evident to the world that media is already in need of introspection, role reconsideration and self-criticism in this regard , a recent example being Bill Moyers' "Buying the War" documentary highlighting serious lapses on the media's part in case of coverage leading to the Iraq war. The international media leaves no stone unturned to highlight the controversies surrounding the Danish cartoons and the papal controversy but it must also give coverage and bring into the limelight, all the peaceful educational and interfaith initiatives taken by Muslims in America and worldwide.

The researcher, very openheartedly accepts that there are also examples of the International media supporting the beliefs and practices of the Muslims. There is no doubt that it has on several occasions raised a voice more effectively for supporting the genuine issues of the Muslims than the media of Muslim countries even. One such example of the media highlighting lack of ablution facilities for Muslim students studying in American universities is a testimony meriting credit; The American media highlighted the issue of lack of washing facilities for Young Muslim students in American universities, which resulted in the installation of footbaths, for ablution, worth thousands of dollars in universities like Howard, Stanford, Michigan and Boston. This initiative on the part of American universities has gone a long way to show the world that Muslims students are welcome, indeed.

\section{Conclusion}

Last but not the least, being the opinion makers, Media needs to understand the social rules in a multicultural world. Charles Darwin, the originator of evolutionary theory, claimed that the basic modes of emotional expression are the same in all human beings. Therefore the responsible people in the world of media must under no condition allow ridiculing of sacred personalities, prophets, saints and incidents of torching of the divine books. As such incidents would surely generate feelings of sadness, anger and disgust. Just as we regard social etiquettes or politeness important in social gatherings and we refrain from making jokes about someone's baldness, if we realize that the person is wearing a false wig. Similarly, tact must be exercised about other people's sensitivities.

\section{Recommendations}

My humble suggestions with regards to Media's role in creating tolerant societies are as follows:

1.Expert social/ political reporters be hired who are grounded in media ethics so that they offer thoughtful, fair and meticulous treatment to social and political issues and policies There must be award citations for best journalist, best columns, articles, talk shows and documentaries.

2. A batch of impartial, objective, expert Foreign and indigenous Correspondents must be groomed by the media groups for reporting research based news items who could offer an in depth analysis of the events in its proper context and perspective.

3. Dilating upon the power and authority that media has over our minds, an American Pastor, Joel Osteen remarked "If Jesus were here today, he wouldn't be riding around on a donkey. He'd be taking a plane; he'd be using the media". So if the media is so pervasive then the economists, the financial analysts must be given adequate space by the editors and the higher authorities to cover topics such as the basic cause of poverty and economic recession around the world .Media alone can urge the rich nations not to waste food. There is surely enough food in the developed countries where good fertilizers and advanced farming techniques, continue to increase the yield yearly, more than the population growth rate. The surplus food must be used to feed hungry mouths around the world.

4. In addition to media, another category of opinion leaders or people who enjoy authority and popularity over the masses and can be used as subjects to frame documentaries are people like the Pakistani sportsman politician cum philanthropist of international stature, Imran Khan; Mother Teresa who is universally respected for her service to humanity. Yvonne Riddley, a British journalist is also respected in the Muslim world due to her accomplishments in the field of journalism and human rights. The achievements and advice of people like Nelson Mandela, messages and testimonials of leaders from the category of scholars and writers, messages of spiritual leaders and teachings of mystic poets may be disseminated through media to bridge the cross cultural gaps.

5. There must always be a good number of conscientious media persons who can resist pressure either from the editors or owners to slant their news so that they become the torch bearers upholding truth, justice and equity in the world. 


\section{References}

[1] Collins Dictionary of Quotations Edited by Norman Jeffares \& Martin Uray.Printed in Great Britain by Harper Collins Publishers 1995. $\mathrm{Pg} 21$.

[2] Pg 42, Chomsky Noam-The Common Good-Interviewed by David Barsani.Printed in Canada,Nov 2003, Odian Press.

[3] Pg 18 Human Societies_A Reader by Anthony Giddens.Blackwell Publishers Cambridge, UK 1992.

[4] Pg 63, Giddens Sociology. Blackwell Publishers Cambridge, UK 1998.

[5] Pg 65, Giddens Sociology. Blackwell Publishers Cambridge, UK 1998.

[6] The Cambridge Dictionary of Philosophy-2nd Edition.General Editor Robert Audi.Cambridge University Press 1999.

[7] http://www.mediaandislam.com/multimedia/american-opinions-muslims-and-the-media/ 